\title{
Internet usage and experience in online shopping influences the attitude of people about e-market
}

Received: 10.03.2017; Revised: 25.04.2017; Accepted: 12.05.2017

See end of the paper for authors' affiliations

\section{S. LOGESWARI}

Department of Resource Management and Consumer Sciences, College of Home Science, Professor Jayashankar

Telangana State Agricultural University, HYDERABAD (TELANGANA) INDIA Email : mydadmyfav@gmail.com
ABSTRACT : Shopping on various brands and things has become entirely easy across the world through internet. Trade and business works hand in hand with the development of internet usage. Consumers purchase online majorly for new and innovative products which can be compatible for their budget. Sixty respondents were selected for the study using random sampling method in Hyderabad city. A detailed interview schedule was used for collection of information about the internet usage and online shopping attitude among the respondents. Sixty per cent of the total study population has done online purchase. Majority (78\%) of the respondents expressed themselves as intermediate in proficiency level of internet usage. Non online shoppers have also reported that they check to online products and their price before they go to retail stores for purchase. There is a significant variation among the proficiency level and attitude of the students, towards positive correlation. Thus, internet usage has influenced the respondents to involve in online shopping and creates a positive attitude towards the purchase of online goods.

KEY WORDS: Online shopping, E-market, Marketing, Students, Internet usage

- HOW TO CITE THIS PAPER : Logeswari, S. and Mrunalini, A. (2017). Internet usage and experience in online shopping influences the attitude of people about e-market. Asian J. Home Sci., 12 (1) : 213-216, DOI: 10.15740/HAS/AJHS/12.1/213-216. 